\title{
Actinomyces neuii Subspecies neuii
}

National Cancer Institute

\section{Source}

National Cancer Institute. Actinomyces neuii Subspecies neuii. NCI Thesaurus. Code

C119313.

A species of anaerobic rod-shaped or coccoid coryneform group 1 bacteria belong ing to the genus Actinomyces that reduces nitrate, ferments carbohydrates, and is commonly found as a human pathogen in tissue, bone and blood stream infections. 